\title{
ДОСЛІДЖЕННЯ ВОДОРЕДУКУЮЧОГО ЕФЕКТУ БЕТОННОЇ СУМІШ ПРИ ЗАСТОСУВАННІ ПЛАСТИФІКАТОРА БІОПЛАСТ
}

\section{RESEARCH OF THE WATER-DUCTING EFFECT OF CONCRETE MIXTURE WITH THE APPLICATION OF BIOPLAST PLASTIFICATOR}

\begin{abstract}
Кислюк Д.Я., к.т.н., доц., Чапюк О.С., к.т.н., доц., Ротко С.В., к.т.н., доц., Самчук В.П., к.т.н., доц., (Луцький національний технічний університет, м. Луцьк), Савенко В. І. к.т.н., доцент (КНУБА, м. Київ)
\end{abstract}

Kyslyuk D.Y., Ph.D. in Engineering, Associate Professor, Chapiuk O.S., Ph.D. in Engineering, Associate Professor Rotko S.V., Ph.D. in Engineering, Associate Professor, Samchuk V.P. Ph.D. in Engineering, Associate Professor (Lutsk National Technical University, Lutsk), Savenko V.I. Ph.D. in Engineering, Associate Professor (Kyiv National University of Construction and Architecture, Kyiv)

Анотація. Наведено дослідження виливу біополімерного пластифікатора «Біопласт-1» з упареної мелясної барди, яка є вторинним відходом виробництва біоетанолу. У роботі наведені результати. випробування бетонних зразків із пластифікатором Біопласт-1, які показали можливість зниження витрати води в основній бетонній сумімі.

Summary. At present, the vast majority of concrete mixtures are made using plasticizers, which increase their mobility, convenience, reduce the energy and labor costs when enclosing monolithic building structures, facilitate the intensification of the technological cycle, and enhance the quality of structures.

There is a large number of types of plasticizers, but in the city of Lutsk at the microbiooprom plant from the steamed molasses bards, which is a secondary waste of bioethanol production, an ecological biopolymer plasticizer Bioplast-1 was obtained, the properties of which have not yet been studied.The plaster is made on the basis of environmentally safe biopolymers that form useful, safe microorganisms - cellulose type, lignin-pectin type (microfibre), hydrocarbon, protein type (polymer molecule), alkali metals (potassium, sodium), alkaline earth metals (calcium, magnesium), phosphorus compounds and other biocomponents. Bioplast-1 is a dense syrup liquid of dark brown color with a concentration of substances of $50-60 \%$, a density of 1,25 - 1,29 g/ cm3. It is used for the production of prefabricated reinforced concrete pre-stressed and monolithic structures, for use in non-aggressive and aggressive gas and water environments.

In the paper the influence of the plasticizing ecological additive from the alcoholic waste production on the mobility of the concrete mixture and the strength of the concrete 
cubes is considered. The work also establishes the criteria and properties of a plasticizer additive.The work was carried out in two stages: the first stage consisted in the study of the plasticization effects of the additive "Bioplast-1" on the concrete mixture; The second stage included the determination of the effect of the additive on the strength of concrete cubes.The study of the effectiveness of the additive was performed to determine the main effect, to achieve which the additive is intended and an experimental refinement of the optimal dosage of the additive.Bioplast-1 plasticizers have criteria for water-reducing effect and are highly water-reducing.Testing of concrete specimens with Bioplast-1 plasticizer showed the possibility of reducing the water flow rate in the main concrete mix (WRE) by up to 13\%. The increase in strength of cubes with the addition of Bioplast$1 B L$ was up to $16 \%$, with the addition of Bioplast-1L - up to $21 \%$.

Ключові слова: пластифікатори, біотехнологічна добавка, рухливість бетонної суміші, мічність на стиск.

Keywords: plasticizer, biotechnological additive, mobility of concrete mix, compressive strength

Постановка проблеми. На сьогодні переважна більшість бетонних сумішей виготовляється із використанням пластифікаторів, які підвищують їх рухливість, легкоукладальність, зменшують енерго- та трудовитрати при укладанні в опалубку монолітних будівельних конструкцій, сприяють інтенсифікації технологічного циклу, підвищенню якості конструкцій [1].

У якості пластифікуючих добавок широко використовують поверхнево-активні речовини (ПАР). Типовими представниками добавок ПАР із вираженими пластифікуючими властивостями $є$ добавки на базі відходів або побічних продуктів промисловості (ССБ, СДБ, ЛСТ) i синтетичні суперпластифікатори (СП). Добавки цієї групи найбільш ефективні в бетонних сумішах з відносно високою витратою цементу. Як пластифікуючі добавки використовуються суперпластифікатор полікарбоксилатного типу Melflux (BASF, Німеччина), суперпластифікатор нафталін-сульфонатного типу C-3, пластифікатор на основі полікарбоксилатів і поліакрилатів СП-1, суперпластифікатор на основі сульфованих меламіноформальдегідних поліконденсатів МФ, модифіковані пластифікатори лігносульфонатного типу ЛСТМ та інші.

ТзОВ «Мікробіопром» у м. Луцьку на основі меляси організовує виробництво біотехнологічного пластифікатора бетонів, цементних розчинів, інших будівельних розчинів «Біопласт-1».

Пластифікатор виготовлений на основі екологічно безпечних біополімерів, які утворюють корисні, безпечні мікроорганізми целюлозного типу, лігнін-пектинового типу (мікроволокна), вуглеводневого, білкового типу (полімерні молекули), лужних металів (калій, натрій), лужноземельних металів (кальцій, магній), фосфорних сполук та інших біокомпонентів. Біохімічний склад та вигляд добавки був 
встановлений ТОВ «Науково-виробнича біотехнологічна фірма «Мікробіопром».

На даний час отримано дві модифікації пластифікатора «Біопласт-1»: Біопласт-1БЛ i Біопласт-1Л. Хімічний склад кожної 3 них дещо відрізняється один від одного та від упареної післядріжджової барди, дія якої на будівельні розчини відома. Тому необхідно було вивчити вплив різних видів біотехнологічного пластифікатора «Біопласт-1» на властивості бетонної суміші, міцність бетону, можливості застосування та витрати пластифікуючої добавки.

Аналіз відомих досліджень. Водоредукуючі добавки, наприклад C-3, дозволяють управляти проникністю бетону. Ще в 50-ті роки M.I. Хигерович відзначав, що введення пластифікаторів істотно модифікує порову структуру бетону, зменшуючи іï розмір. За рахунок використання комплексної добавки С-3 був отриманий бетон із високим рівнем водонепроникності (W18).

До пластифікаторів, які дозволяють зменшити водопотребу бетону з забезпеченням заданої рухомості суміші, відносяться комплексні добавки. Проведені дослідження показали можливість раціонального поєднання суперпластифікаторів полікарбоксилатного типу 3 пластифікуючими добавками інших видів і створення ефективних комплексних добавок, що характеризуються високими пластифікуючим і водоредукуючим ефектами та зниженням вартості добавок. Розроблені склади високоміцних бетонів класів С $80 \ldots \mathrm{C} 100$, які набувають міцності при нормальному твердінні до 70\% від нормативної через 12 годин [3].

Результати експериментальних досліджень. Робота виконувалася у два етапи: перший етап полягав у дослідженні пластифікуючого ефекту добавки «Біопласт-1» на бетонну суміш [4]; другий етап включав в себе визначення впливу добавки на міцність бетонних кубів.

Програмою випробувань було передбачено виготовити та випробувати 13 серій бетонних зразків для дослідження рухливості бетонної суміші та кубикової міцності бетону у віці 7 діб та 28 діб і пропарених кубів на 2 добу.

Робота виконувалася для дослідження пластифікуючого ефекту на бетонну суміш та визначення впливу добавки на міцність бетонних кубів. Дослідження рухливості бетонної суміші та міцність бетонних кубів 3 введенням добавки Біопласт-1 за однакового водоцементного відношення було встановлено ефективність застосування біотехнологічного пластифікатора. Пластифікатор Біопласт-1БЛ відповідає пластифікуючим добавкам [5]. Використання добавки концентрацією $0,35-1,0 \%$ від маси цементу, викликає збільшення рухомості бетонної суміші на два ступені від Р1 до Р3 (від 3-4 см до 13-14 см). Пластифікатор Біопласт-1Л концентрацією від $0,35 \%$ до $1 \%$ викликає збільшення рухомості бетонної 
суміші на один ступінь - від Р1 до Р2 (від 3-4 см до 8-9 см) та може збільшувати міцність бетону до 10\% [6].

Дослідження водоредукуючого ефекту (ВРЕ). Випробування бетонних сумішей за однакової консистенції відбувалось при зменшенні водоцементного відношення в бетонній суміші 3 добавкою Біопласт-1 3 В/Ц=0,46 до В/Ц=0,4.

Визначення ВРЕ виконували за формулою:

$$
B P E=\frac{B-B_{0}}{B_{0}} \cdot 100 \%
$$

де В - витрата води при додаванні пластифікуючої добавки без зменшення початкової рухомості осідання;

Во - витрата води для бетонної суміші без вмісту пластифікатора.

Зниження витрати води в основній бетонній суміші у порівнянні 3 контрольною склала ВРЕ $=13 \%$, що за критерієм ефективності відповідає супер водоредукуючим добавкам.

Випробування бетонної суміші за концентрації пластифікатора Біопласт-1БЛ 0,5\% і 0,7\%, показало осідання конуса 4,5 см та 5,4 см відповідно. В бетонній суміші 3 добавкою Біопласт-1Л отримали такі результати рухливості: при концентрації пластифікатора $0,5 \%$ $\mathrm{OK}=1,5$ см; при концентрації $1,0 \%-\mathrm{OK}=4 \mathrm{~cm}$; при $1,5 \%-\mathrm{OK}=5,4$ см. Осідання конуса контрольної суміші становило 3,5 см. При збільшенні кількості добавки спостерігалось збільшення рухливості бетонної суміші. Отже, використання в бетонах добавки концентрації 0,5\% Біопласт-1БЛ та $1,0 \%$ Біопласт-1Л дозволяє знизити витрати води на $13 \%$ та забезпечити рухливість бетонної суміші на рівні контрольних зразків (марка за легкоукладальністю Р1). Для збільшення водоредукуючого ефекту потрібно збільшити концентрацію пластифікатора.

Дослідження пластифікуючого ефекту (ПЕ). Ефективність комплексного впливу факторів (зменшення В/Ц та збільшення кількості добавки) на рухомість суміші оцінювали за величиною пластифікуючого ефекту, який визначався за формулою:

$$
\Pi E=\frac{O K-O K_{0}}{O R_{0}} \times 100 \%
$$

де ОК - осідання конуса при додаванні пластифікуючої добавки;

$\mathrm{OK}_{\text {o }}$ осідання конуса контрольного складу.

Пластифікуючий ефект добавки для бетонних сумішей з В/Ц $=0,4$ до контрольного бетону при вмісті пластифікатора Біопласт-1БЛ 0,5\% та 0,7\% від маси цементу знаходився в межах відповідно від $29 \%$ до 54\%. Для добавки Біопласт-1Л пластифікуючий ефект становив 14\% та 54\% при концентрації відповідно $1 \%$ та 1,5\%. Ефект застосування пластифікатора Біопласт-1БЛ в 1,5 рази вищий за Біопласт-1Л (рис. 1). 


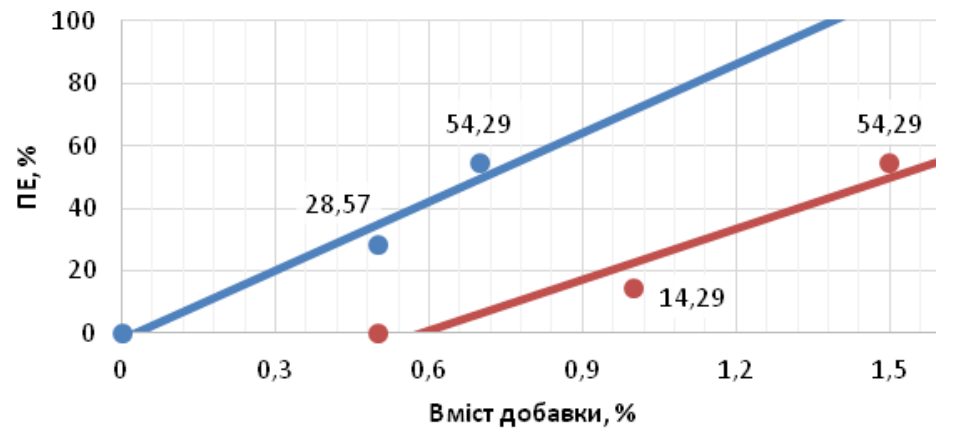

- Біопласт-1 БЛ

- Біопласт-1 Л

Рис. 1. Вплив кількості добавок на пластифікуючий ефект

Механічні характеристики бетону (кубова міцність) при одноразовому короткочасному навантаженні визначались на гідравлічному пресі ПСУ-125 (з ціною поділки 2,5кН). Кубикову міцність бетону визначали у віці 7 і 28 діб. Результати випробувань наведені в таблиці 1.

При випробуванні контрольних кубиків (КК) на стиск у віці 7 діб міцність склала $f_{\text {cm,cube }}=32,69$ МПа. У віці 28 діб було виконане випробування відповідних бетонних кубів, які показали суттєве збільшення міцності бетону. Цей приріст в середньому склав $43 \%$, а міцність становила $f_{\text {cm, сube }}=46,69$ МПа. Міцність кубів після твердіння у пропарювальній камері становила $f_{c m, c u b e}=39,54$ МПа.

Дослідження міцності бетону при зниженні В/Ц. Пряма залежність між підвищенням міцності і ВРЕ спостерігається при збільшенні вмісту в бетоні добавки. Випробовування кубів КБ-0,5* і КБ-0,7* дозволяє оцінити водоредукуючий ефект пластифікатора Біопласт-1БЛ. Міцність бетонних зразків КБ- $0,5 *$ збільшується на $16 \%$ від міцності контрольних кубів до $f_{\text {cm,cube }}=54,16$ МПа, в кубах КБ- $0,7 *-$ на $13,8 \%$ до $f_{c m, \text { cube }}=53,15$ МПа у віці 28 днів.

Міцність бетону на стиск при зменшенні водоцементного відношення $(\mathrm{B} / Ц=0,4)$ в кубах КЛ-0,5* із використанням пластифікатора Біопласт-1Л зростає на $21 \%$ - до $f_{\text {cm, cube }}=56,68$ МПа. При концентрації пластифікатора $1 \%$ приріст кубикової міцності склав $12 \%$ - до $f_{c m, c u b e}=52,37 \mathrm{MПа,} \mathrm{а} \mathrm{в}$ зразках КЛ-1,5* міцність падає до значень у контрольних зразках - до $f_{\text {cm,cube }}=47,58$ МПа. Порівняння результатів випробувань на 7-й день та після пропарювання показали схожі результати, лише в кубах КЛ-1,5* прирости міцності відрізнялись один від одного. 
Таблиця 1

Результати випробувань 3 дослідження впливу пластифікатора

\begin{tabular}{|c|c|c|c|c|c|c|}
\hline \multirow{2}{*}{ № } & \multirow{2}{*}{ Вид бетонних зразків } & \multirow{2}{*}{$\mathrm{OK}$} & \multirow{2}{*}{$\begin{array}{c}\text { Рухли- } \\
\text { вість }\end{array}$} & \multicolumn{3}{|c|}{ Міцність бетону $f_{\text {cm, cube }}$ МПа } \\
\hline & & & & ПП & 7 днів & 28 днів \\
\hline \multicolumn{7}{|c|}{ Біопласт-1БЛ } \\
\hline 1 & Куби контрольні (КК-1) & 3,50 & $\mathrm{P} 1$ & 39,54 & 32,69 & 46,69 \\
\hline 2 & $\begin{array}{c}\text { Куби з добавкою } 0,35 \% \\
\text { пластифікатора «Біопласт-1БЛ» } \\
(\text { КБ- } 0,35)\end{array}$ & 12,50 & P3 & 36,51 & 33,57 & 47,19 \\
\hline 3 & $\begin{array}{c}\text { Куби з добавкою 0,5\% } \\
\text { пластифікатора «Біопласт-1БЛ» } \\
(\text { КБ- } 0,5)\end{array}$ & 12,80 & P3 & 38,17 & 35,17 & 45,95 \\
\hline 4 & $\begin{array}{c}\text { Куби з добавкою 1\% } \\
\text { пластифікатора «Біопласт-1БЛ» } \\
\text { (КБ-1) }\end{array}$ & 13,50 & P3 & 37,36 & 33,05 & 44,63 \\
\hline 5 & $\begin{array}{c}\text { Куби з добавкою 1,5\% } \\
\text { пластифікатора «Біопласт-1БЛ» } \\
(\text { КБ- } 1,5)\end{array}$ & 13,80 & P3 & 35,57 & 31,88 & 40,96 \\
\hline 6 & $\begin{array}{c}\text { Куби з добавкою } 0,5 \% \\
\text { пластифікатора «Біопласт-1БЛ» } \\
\left(\text { КБ- } 0,5^{*}\right) \text { В/Ц=0,4 }\end{array}$ & 4,50 & $\mathrm{P} 1$ & 43,96 & 36,06 & 54,16 \\
\hline 7 & $\begin{array}{c}\text { Куби з добавкою 0,7\% } \\
\text { пластифікатора «Біопласт-1БЛ» } \\
\left.\text { (КБ- } 0,7^{*}\right) \text { В/Ц= }=0,4\end{array}$ & 5,40 & $\mathrm{P} 2$ & 46,21 & 39,03 & 53,15 \\
\hline \multicolumn{7}{|c|}{$\begin{array}{l}\text { Біопласт-1Б } \\
\end{array}$} \\
\hline 1 & Куби контрольні (КК-1) & 3,50 & $\mathrm{P} 1$ & 39,54 & 32,69 & 46,69 \\
\hline 2 & $\begin{array}{c}\text { Куби з добавкою 0,35\% } \\
\text { пластифікатора «Біопласт-1Л» } \\
(\text { КЛ-0,35) }\end{array}$ & 7,00 & $\mathrm{P} 2$ & 39,41 & 35,32 & 48,35 \\
\hline 3 & $\begin{array}{c}\text { Куби з добавкою 0,5\% } \\
\text { пластифікатора «Біопласт-1Л» } \\
(\text { КЛ- } 0,5)\end{array}$ & 8,40 & $\mathrm{P} 2$ & 37,56 & 36,89 & 49,14 \\
\hline 4 & $\begin{array}{c}\text { Куби з добавкою 1\% } \\
\text { пластифікатора «Біопласт-1Л» } \\
\text { (КЛ-1) }\end{array}$ & 9,00 & $\mathrm{P} 2$ & 36,58 & 33,01 & 49,98 \\
\hline 5 & $\begin{array}{c}\text { Куби з добавкою 0,5\% } \\
\text { пластифікатора «Біопласт-1Л» } \\
\left(\text { КЛ- } 0,5^{*}\right) \text { В/Ц=0,4 }\end{array}$ & 1,50 & $\mathrm{P} 1$ & 47,81 & 40,70 & 56,68 \\
\hline 6 & $\begin{array}{c}\text { Куби з добавкою 1\% } \\
\text { пластифікатора «Біопласт-1Л» } \\
\left.\text { (КЛ- } 1^{*}\right) \text { В/Ц=0,4 }\end{array}$ & 4,00 & $\mathrm{P} 1$ & 46,68 & 36,89 & 52,37 \\
\hline 7 & $\begin{array}{c}\text { Куби з добавкою 1,5\% } \\
\text { пластифікатора «Біопласт-1Л» } \\
(\text { КЛ-1,5*) В/Ц=0,4 }\end{array}$ & 5,40 & P2 & 44,99 & 35,70 & 47,58 \\
\hline
\end{tabular}


Отже, пластифікатори Біопласт-1БЛ та Біопласт-1Л мають критерії сильноводоредукуючої добавки за ДСТУ Б В.2.7-171. Ефективна кількість добавок з урахуванням всіх факторів лежить у межах $0,5-1,0 \%$ від маси цементу.

Висновки. Пластифікатори Біопласт-1БЛ та Біопласт-1Л мають критерії водоредукуючого ефекту та відповідають сильноводоредукуючим за ДСТУ Б В.2.7-171.

Випробування бетонних зразків із пластифікатором Біопласт-1 показало можливість зниження витрати води в основній бетонній суміші (ВРЕ) до 13\%. При цьому збільшення міцності кубів з добавкою Біопласт1БЛ складало до 16\%, із добавкою Біопласт-1Л - до 21\%.

Ефективні концентрації біотехнологічних пластифікаторів Біопласт1БЛ Біопласт-1Л для приготування бетонних сумішей в межах від 0,35 до 1,0\% від маси цементу.

\section{References}

1. Bazhenov Yu.M. Tekhnolohyia betona. Uchebnyk. Moskva.: Yzd-vo ASV, 2002. $500 \mathrm{~s}$.

2. Dvorkin L.Y., Zhytkovskyi V.V., Skrypnyk M.M. Kompleksni plastyfikuiuchi dobavky dlia betonu na osnovi efiriv polikarboksylatu. Stroytelnыe materyalы у yzdelyia. Kyiv. 2016. \#1. S. 38-41.

3. Dvorkin L.Y., Babych Ye.M., Zhytkovskyi V.V. ta in. Vysokomitsni shvydkotverdnuchi betony ta fibrobetony: monohrafiia. Rivne: NUVHP, 2017. 331s.

4. DSTU B V.2.7-114-2002 Sumishi betonni. Metody vyprobuvan Kyiv:, 2002.

5. DSTU B V.2.7-171:2008 Dobavky dlia betoniv i budivelnykh rozchyniv.- Kyiv: Minrehionbud Ukrainy, 2010.

6. Kysliuk D.Ya., Rotko S.V., Kantseliarchyk O.M., Petrychuk R.M. Doslidzhennia vplyvu zastosuvannia plastyfikatora Bioplast na vlastyvosti betonnoi sumishi. Suchasni tekhnolohii ta metody rozrakhunkiv u budivnytstvi: zb. nauk. prats Lutsk: Lutskyi NTU, 2019. - Vyp. 11. - S. 31-37.

\section{Список використаної літератури}

1. Баженов Ю.М. Технология бетона. Учебник. Москва.: Изд-во АСВ, 2002. $500 \mathrm{c}$.

2. Дворкін Л.Й., Житковський В.В., Скрипник М.М. Комплексні пластифікуючі добавки для бетону на основі ефірів полікарбоксилату. Строительные материалы и изделия. Київ. 2016. №1. С. 38-41.

3. Дворкін Л.Й., Бабич С.М., Житковський В.В. та ін. Високоміцні швидкотверднучі бетони та фібробетони: монографія. Рівне: НУВГП, 2017. 331с.

4. ДСТУ Б В.2.7-114-2002 Суміші бетонні. Методи випробувань Київ:, 2002.

5. ДСТУ Б В.2.7-171:2008 Добавки для бетонів і будівельних розчинів.- Київ: Мінрегіонбуд України, 2010.

6. Кислюк Д.Я., Ротко С.В., Канцелярчик О.М., Петричук Р.М. Дослідження впливу застосування пластифікатора Біопласт на властивості бетонної суміші. Сучасні технології та методи розрахунків у будівництві: зб. наук. праць - Луцьк: Луцький НТУ, 2019. - Вип. 11. - С. 31-37. 